\title{
Using 3D Computer Modeling, Borehole Geophysics, and High Capacity Pumps to Restore Production to Marginal Wells in the East Texas Field
}

\author{
Final Technical Report
}

Reporting Period Start Date: March 11, 2002

Reporting Period End Date: March 10, 2003

Prepared by:

R.L. Bassett, Ph.D.

TENECO Energy, LLC

3760 Vance St., Suite 200

Wheat Ridge, CO 80033

June 9, 2003

DOE Award Number: DE-FG26-02NT15267 


\section{DISCLAIMER}

This report was prepared as an account of work sponsored by an agency of the United State Government. Neither the United States Government nor any agency thereof, nor any of their employees, makes any warranty, express or implied, or assumes any legal liability or responsibility for the accuracy, completeness, or usefulness of any information, apparatus, product, or process disclosed, or represents that its use would not infringe privately owned rights. Reference herein to any specific commercial product, process, or service by trade name, trade mark, manufacturer, or otherwise does not necessarily constitute or imply its endorsement, recommendation, or favoring by the United States Government or any agency thereof. The views and opinions of authors expressed herein do not necessarily state or reflect those of the United States Government or any agency thereof. 


\begin{abstract}
Methods for extending the productive life of marginal wells in the East Texas Field were investigated using advanced computer imaging technology, geophysical tools, and selective perforation of existing wells. Funding was provided by the Department of Energy, TENECO Energy and Schlumberger Wireline and Testing. Drillers’ logs for more than 100 wells in proximity to the project lease were acquired, converted to digital format using a numerical scheme, and the data were used to create a 3 Dimensional geological image of the project site. Using the descriptive drillers' logs in numerical format yielded useful cross sections identifying the Woodbine Austin Chalk contact and continuity of sand zones between wells. The geological data provided information about reservoir continuity, but not the amount of remaining oil, this was obtained using selective modern logs. Schlumberger logged the wells through 2 3/8” tubing with a new slimhole Reservoir Saturation Tool (RST) which can measure the oil and water content of the existing porosity, using neutron scattering and a gamma ray spectrometer (GST). The tool provided direct measurements of elemental content yielding interpretations of porosity, lithology, and oil and water content, confirming that significant oil saturation still exists, up to $50 \%$ in the upper Woodbine sand. Well testing was then begun and at the end of the project new oil was being produced from zones abandoned or bypassed more than 25 years ago.
\end{abstract}




\section{TABLE OF CONTENTS}

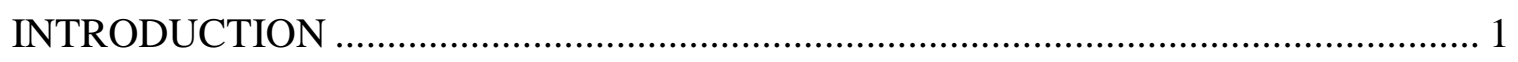

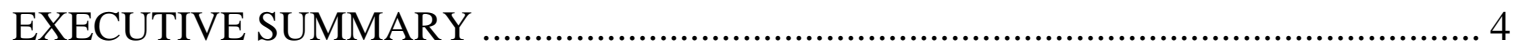

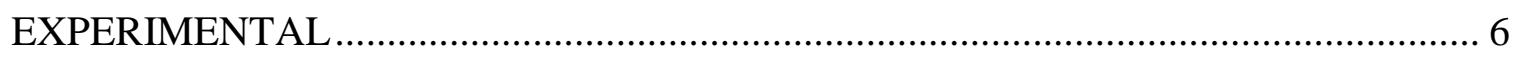

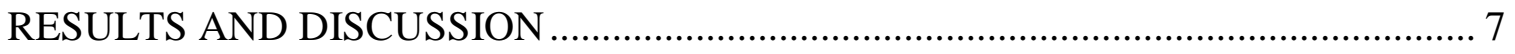

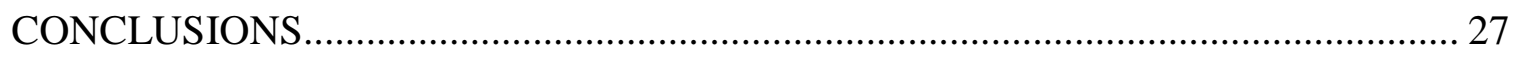

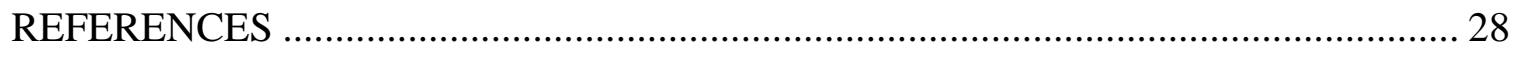




\section{LIST OF GRAPHICAL MATERIAL}

Figure 1. Regional location map for the East Texas Field.............................................. 3

Figure 2. Location of the project lease outlined in red with surrounding leases and wells.

Figure 3. Page 1 of a typical drillers' log filed in the 1930's when the East Texas Field was first discovered. Records are available from the Texas Railroad Commission.. 9

Figure 4. Page 2 of a typical drillers' log filed in the 1930's when the East Texas Field was first discovered. Records are available from the Texas Railroad Commission.10

Figure 5. Distribution of wells from which drillers' logs were available in the proximity of the project lease.

Figure 6. East -west section through the lease depicting the Woodbine sand. The dark blue correlates the oil sand and clean sand zones and the green indicates increasing clay content. Austin Chalk or carbonate sediments are displayed in red. Lease lines are superimposed at the top of the image and wells from which drillers' logs were obrtained are shown as wellbores. Green wellbores are producing wells and red wellbores are plugged or shut-in wells. Vertical scale is exagerated bu th eentire Woodbine sand section is approximately 150 feet thick. Horizontal scale across the image is approximately 2 miles.

Figure 7. A north-south section through wells Nos. 8 \& 9 located on the stratigraphic high point of the Woodbine sand. The dark blue correlates the oil sand and clean sand zones and the green indicates increasing clay content. Austin Chalk or carbonate sediments are displayed in red. Lease lines are superimposed at the top of the image and wells from which drillers' logs were obrtained are shown as wellbores. Green wellbores are producing wells and red wellbores are plugged or shut-in wells. Vertical scale is exagerated bu th eentire Woodbine sand section is approximately 150 feet thick. Horizontal scale across the image is approximately 2 miles.

Figure 8. A north-south section through wells No. 5 located on the stratigraphic high point of the Woodbine sand. The dark blue correlates the oil sand and clean sand zones and the green indicates increasing clay content. Austin Chalk or carbonate sediments are displayed in red. Lease lines are superimposed at the top of the image and wells from which drillers' logs were obrtained are shown as wellbores. Green wellbores are producing wells and red wellbores are plugged or shut-in wells. Vertical scale is exagerated bu th eentire Woodbine sand section is approximately 150 feet thick. Horizontal scale across the image is approximately 2 miles. 16

Figure 9. A north-south section through well No. 7 located on the stratigraphic high point of the Woodbine sand although the prominence of the sand has flattened. The dark blue correlates the oil sand and clean sand zones and the green indicates increasing clay content. Austin Chalk or carbonate sediments are displayed in red. Lease lines are superimposed at the top of the image and wells from which drillers' logs were obrtained are shown as wellbores. Green wellbores are producing wells and red wellbores are plugged or shut-in wells. Vertical scale is exagerated bu th eentire Woodbine sand section is approximately 150 feet thick. Horizontal scale across the image is approximately 2 miles. 
Figure 10. A top view of the project lease with north-south sections through each lease well. Note the stratigraphic ridge through the center of the lease. The dark blue correlates the oil sand and clean sand zones and the green indicates increasing clay content. Austin Chalk or carbonate sediments are displayed in red. Lease lines are superimposed at the top of the image and wells from which drillers' logs were obrtained are shown as wellbores. Green wellbores are producing wells and red wellbores are plugged or shut-in wells. Vertical scale is exagerated bu th eentire Woodbine sand section is approximately 150 feet thick. Horizontal scale across the image is approximately 2 miles.

Figure 11. RST-C log of well No. 1. The second panel is the computed log for saturation; dark green is the TDT and the light green is the GST. The third panel displays the distinct contact of the Austin Chalk (blue) and the top of the Woodbine sand ( 3587') shown in yellow, and indicates that the oil saturation is approximtely $50 \%$.

Fig 12. RST-C log of well No. 5. The fifth panel is the computed log for saturation; dark green is the TDT and the light green is the GST. The sixth panel displays the distinct contact of the Austin Chalk (blue) and the top of the Woodbine sand ( $\sim 3595$ ') shown in yellow, and indicates that the oil saturation is approximtely $50 \%$.

Fig.13. RST-C log of well No. 9. The fifth panel is the computed log for saturation; dark green is the TDT and the light green is the GST. The sixth panel displays the distinct contact of the Austin Chalk (blue) and the top of the Woodbine sand ( $\sim 3622 ')$ shown in yellow, and indicates that the oil saturation is approximtely $50 \%$. 


\section{LIST OF TABLES}

Table 1. Conversion chart for Drillers' log descriptive lithology to numerical format... 11

Table 2. An example of a database record containing numeric values for the driller's and

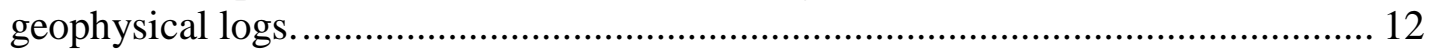

Table 3. Logging parameters employed for the RST-GST tool................................... 20 


\section{INTRODUCTION}

\section{Objective}

The objectives were to: 1.) use advanced 3D Computer Reservoir Imaging Technology to create subsurface geologic images of the reservoir using drillers' logs and other available data. 2.) employ advanced borehole geophysics technology on one of the many marginally economic leases in the East Texas Field to evaluate residual oil distribution after 4 decades of production. 3.) install a high capacity submersible pump in a well with potential for increasing production based on the computer mapped zones and geophysical logs. The use of the high capacity pump was replaced with a process of selective perforation of high potential zones when it was determined that the reservoir produced low total fluid volume in the project area and greater success would be realized by producing lower volumes of total fluid with higher percentage oil.

\section{Overview}

The East Texas Field was discovered in 1930 and quickly became identified as the largest contiguous oil field in the world, extending over 4 counties, 140,000 acres, and at its peak had 35,000 wells (Figs. 1-2). Total production to date is in excess of 5 billion barrels of oil and an estimated 1.4 billion barrels still remain to be recovered. The field has a strong water drive and oil has been pushed to the eastern edge of the field as production proceeded; consequently, the Woodbine sand zones on the eastern or up-dip edge of the reservoir have produced in excess of 100 per cent of the oil in place due to the migration. Wells on the western edge of the field have progressively gone to a high water percentage and have either been shut-in or plugged. Many leases have been abandoned and the Texas Railroad Commission has been required to assume the plugging liability. A large number of these leases have shut-in wells and are available to us for this project.

Currently fewer than 7000 wells remain in production. Oil production has been reduced in half over the past decade and expectations are that it will reach two-thirds in the coming decade. We proposed using this technological approach to evaluate methods for improving the production in these marginal wells of this historically significant field.

\section{Problem Statement:}

1. Production across much of the field is in the 2 to 10 BOPD range with several hundred BWPD per well being sent to the East Texas Salt Water Disposal system.

2. Most wells were drilled more than 50 years ago.

3. Many if not most wells were drilled and completed beginning in the 1930s time frame; consequently geophysical logs were not available. Where open-hole logging was done, 
in general only electric-logs (E-logs) are available. Subsequently production logging was done using through casing tools like the Chlorine log.

4. Active leases are currently held predominantly by individuals and small independents, few properties are still operated by major oil companies; consequently little innovation or research in new methods of increasing production have been done in the field.

5. Even though the field is primarily stripper production, significant additional reserves remain (>1.4 Billion Barrels estimated by the Texas Bureau of Economic Geology), but current operators in general cannot justify the capital expenditure or cost for expertise for advanced computer software or geophysical technologies.

\section{Solution Investigated}

Recent advances in computer software and borehole geophysics are applicable to this problem. The following technology was used.

3-D Imaging Software. The major oil companies gained access first to these 3Dimentional Reservoir Imaging computer programs such as STRATAMODEL (Landmark Graphics) and have now used them for several years. Few large independents and virtually none of the smaller independent companies have pursued this approach because of cost and absence of reliable data. Nevertheless, the utility of these programs to map and interpolate reservoir properties in 3 dimensions, quickly re-map with new data, rotate in space and slice images into cross sections has more than proved its value to the companies that have access to them in field investigations worldwide. We are certified and have significant experience using this software which was used on this project. The software is now being made more accessible to the industry so that if this project is successful, other operators may see the value of computer simulation and they can have access themselves under leasing options from the vendor.

Borehole geophysics. The tubing in many wells of the remaining wells is $23 / 8$ ” OD, to avoid the cost of pulling casing it was a requirement that the geophysical methods have slimhole capability. We were able to use the new RST-GST logging tool made by Schlumberger which provided the analysis of residual oil as well a lithologic and porosity characterization.

High Capacity Pumps/Selective Perforation. Operators in the field have used walking beam pumping units for production since the reservoir ceased to flow several decades ago. Because of the high water percentage, when volumes exceed several hundred BWPD the wells are not economic and are abandoned. We proposed installing a submersible pump in wells deemed potentially productive; however testing revealed that many of the wells would not produce sufficient total fluid volume to justify the expense. Alternatively, DOE approved pursuing a strategy of using the modeling and geophysical work to identify intervals that could be selectively perforated and produced to obtain the bypassed or residual oil. 


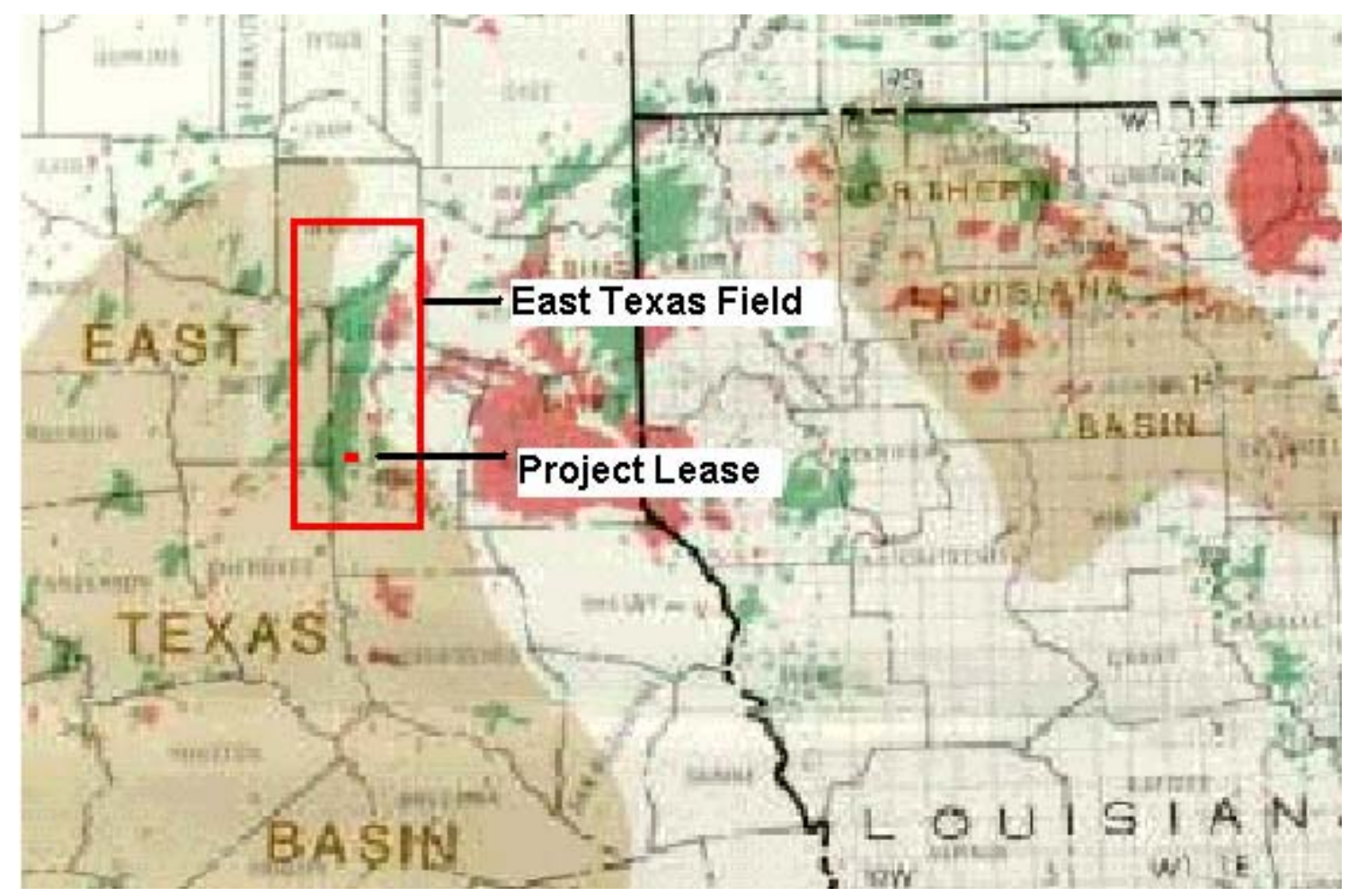

Figure 1. Regional location map for the East Texas Field.

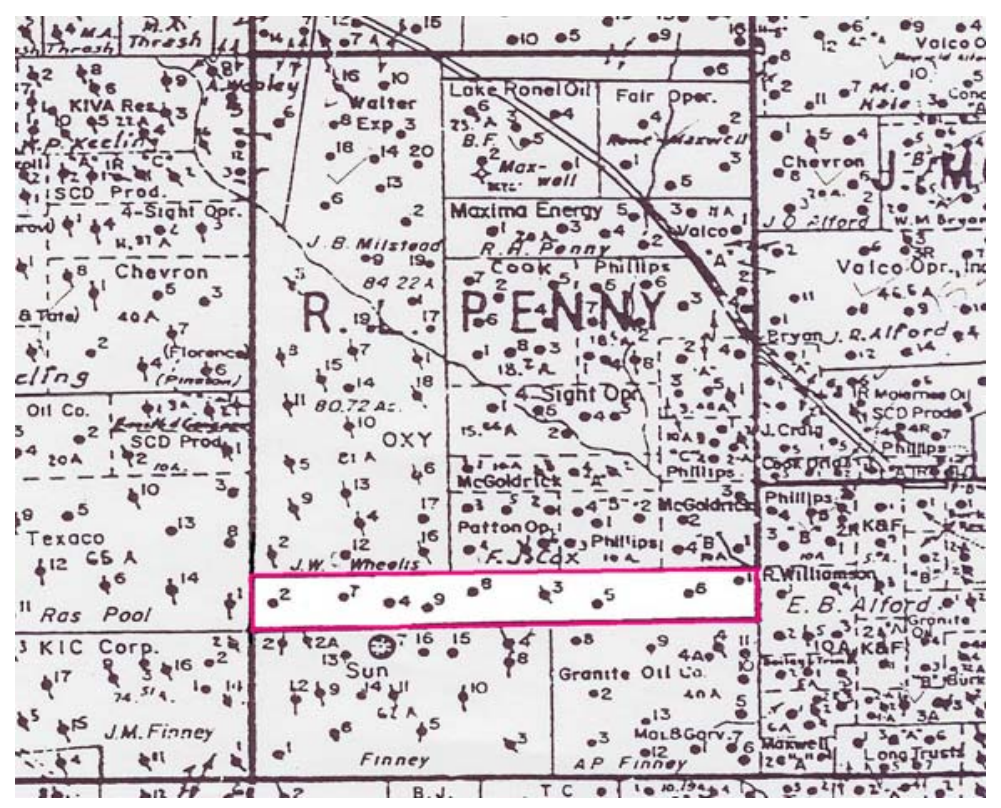

Figure 2. Location of the project lease outlined in red with surrounding leases and wells. 


\section{EXECUTIVE SUMMARY}

Methods for extending the productive life of marginal wells in the East Texas Field were investigated using advanced computer imaging technology, geophysical logging tools, and selective perforation of existing wells. Funding was provided by the Department of Energy, TENECO Energy, and Schlumberger Wireline and Testing. Several candidate wells were selected based on production history and location within the field. The majority of the wells in the East Texas Field were drilled in the 1930's which means that the only information available about the lithology is from the drill cuttings described and recorded as a descriptive record during drilling; open hole geophysical logs were not available at the time. Infill wells drilled at later dates were generally logged and the quality depended on the geophysical technology available at the time the well was drilled. Additionally, production logging has been done for many years; nevertheless, few modern logs are available to the small independent company, which represents the typical operator in the field today.

Drillers' logs for more than 100 wells in proximity to the project lease were acquired from the Texas Railroad Commission or from commercial sources. These drillers' logs were converted to a digital format using a numerical scheme, and the data were input into a modeling package that created a 3 Dimensional geological image of the project site. The data from the drillers' logs in numerical format yielded useful cross sections identifying the Woodbine sand/Austin Chalk contact and continuity of sand zones between wells. This visual representation of sand lenses can be displayed at any angle with any selected cross section and provides the operator with reservoir information that assists in determining the most optimum wells for workovers, re-perforating, and potentially re-injection of water for water-flooding operations. In the absence of openhole geophysical logs, most operators generally rely on through-casing logs of nearby wells to identify sand intervals that may be productive, but data on connectivity of sands or oil saturation are usually unavailable. Mapping the lithologic continuity using drillers' logs and numerical simulation provided a remarkable image of the Woodbine lithology which was far superior to what could be obtained by reading the descriptions of each well. The geological data provides information about reservoir continuity, but not the amount of remaining oil, this was obtained by running a newly developed logging tool from Schlumberger.

Three wells were selected for borehole geophysical logging with the criteria that the data must be acquired through-casing, preferably through-tubing, and yield estimates of residual oil remaining in the Woodbine sand. Schlumberger logged the wells through tubing with a new slimhole Reservoir Saturation Tool (RST) which can measure the oil and water content in the existing porosity, using neutron scattering and a gamma ray spectrometer (GST). The tool provided direct measurements of elemental content of the surrounding formation which when processed yielded interpretations of porosity, 
lithology, and oil and water content, confirming that significant oil saturation still exists, up to $50 \%$ oil was observed in the upper Woodbine sand.

It was determined by using conventional pumping units that the Woodbine sand in this area did not yield large volumes of total fluid and consequently this circumstance did not justify the expense of submersible pumps. Alternatively, with the approval of the Department of Energy the approach taken was to selectively perforate the potentially most productive intervals, and where necessary set a bridge plug to isolate nonproductive zones. Well testing was then begun and at the end of the project new oil was being produced from zones abandoned or bypassed more than 25 years ago. 


\section{EXPERIMENTAL}

1. Computer simulations were done using STRATAMODEL (Landmark Graphics, 1997). STRATAMODEL is a stratigraphic geocellular model that interpolated geologic and engineering properties between points or wells and allows the user to display the interpretations in 3 Dimensions. Cross sections, well locations, surface information can be displayed in orientations defined by the user. No new modifications were made to the computer program. The project demonstrated that descriptive geological and lithologic information could be converted to numerical values displayed in a technical mode.

2. The logging tool used in this project was employed to define geologic properties and detect oil saturation through casing and tubing. The measurements were made with the Reservoir Saturation Tool (RST) made by Schlumberger and is commonly called the carbon/oxygen tool. Details of the measurement methodology and physics are described in Adolph et al., 1994; Schlumberger literature) 


\section{RESULTS AND DISCUSSION}

\section{Project Results}

Numerous leases were available and were excellent candidates for this project. We have selected an area in Rusk County, Texas (Figs. 1-2) where our work to date indicates high probability of remaining oil reserves. We proceeded with the following tasks.

1. 3D Reservoir characteristics modeling using several hundred older E-logs, chlorine logs, and drillers' descriptive logs converted to numerical format

2. Log 3 wells using the Schlumberger tools described above which will provide us with the computed log data on residual oil, and serve as a template for future work.

3. By combining new log data used to obtain oil location and saturation, with old log data to visually describe the reservoir, we were able to determine the optimum well locations for perforation and production..

The logging and computer mapping is the key to locating the residual oil zones in some areas of the field submersible pumps will make the leases economic but in areas such as this with low total fluid volume the selective production is likely the best approach.

\section{Discussion}

\section{Task 1: 3D Geologic Reservoir Simulation}

Detailed engineering, geological, and geophysical information for wells in east Texas is generally sparse and this circumstance has occurred for several reasons: 1.) the wells were drilled in the 1930's and geophysical methods were not employed then so openhole logs are not available and borehole logs are rare; 2.) the field is dominated by small independent companies, ownership of leases has changed many times and what information was available has often been lost during transfers, and 3.) field production data is maintained by lease and not by well, so individual well data is not kept and must be estimated.

The objective in this work was to explore the use of existing data that could be reinterpreted using modern technology. The first attempt was to use driller's logs to provide a depiction of the reservoir. The driller's logs are available for a large percentage of wells but are rarely used because the original records are lost but microfiche copies can be found in the files of the Texas Railroad Commission (TRC). An example of a microfiche copy of one of these driller's records is shown in Figures 3 and 4. The text is barely legible but can be read with effort. The drillers used common and generally accepted terms to describe the cuttings, but because so many wells were drilled in the 
field $(>35,000)$ in close proximity, over a narrow period of time, the terminology and quality of the data is similar among drillers.

The wells drilled in the 1930s were of course not logged with open-hole geophysical tools. Most wells in the East Texas field were never logged later with any of the subsequently developed geophysical tools. Consequently, the driller's record is the only geological information about the well. Records were obtained for more than a hundred wells from the TRC in the vicinity of the project lease. Drillers' logs were correlated with well locations and in most instances could be matched with a specific well. The geologic descriptions and depth listed on the driller's log were converted to digital representation by assigning a numerical value between 0 and 100 to each lithology named on a log. In the conversion scheme devised for this application, the oil sand had the lowest numerical value, sands the low numbers, clay and shale had intermediate values, and carbonates the highest numbers (Table 1).

The purpose in quantifying the descriptive geological terms was to use the numerical equivalents in a $3 \mathrm{D}$ geologic modeling program. The model geostatistically connects the lithology between wells and uses the information about a single well in a geological framework to generate an interpolation of the lithology and lithologic changes between the wells in an area of interest. This resultant $3 \mathrm{D}$ geological image provides a picture of the distribution of reservoir sands and structure that was previously unknown. This would be extremely useful in evaluating whether primitive geological data interpreted with sophisticated software could provide a geological picture of a poorly characterized and complex reservoir, with disconnected sands and clay stringers.

For example, the data similar to that of Figs. 3, 4 were converted to a numerical format using the scheme shown in Table 1, which results in a data file such as is seen in Table 2. These files serve as input to a database used as input to the program by converting the descriptions to numerical format according to the template of Table 1.

An area of interest was defined that included the project lease and as many wells as had driller's logs were included in the database (Figure 5). The simulations were done and the results displayed in a variety of views. 


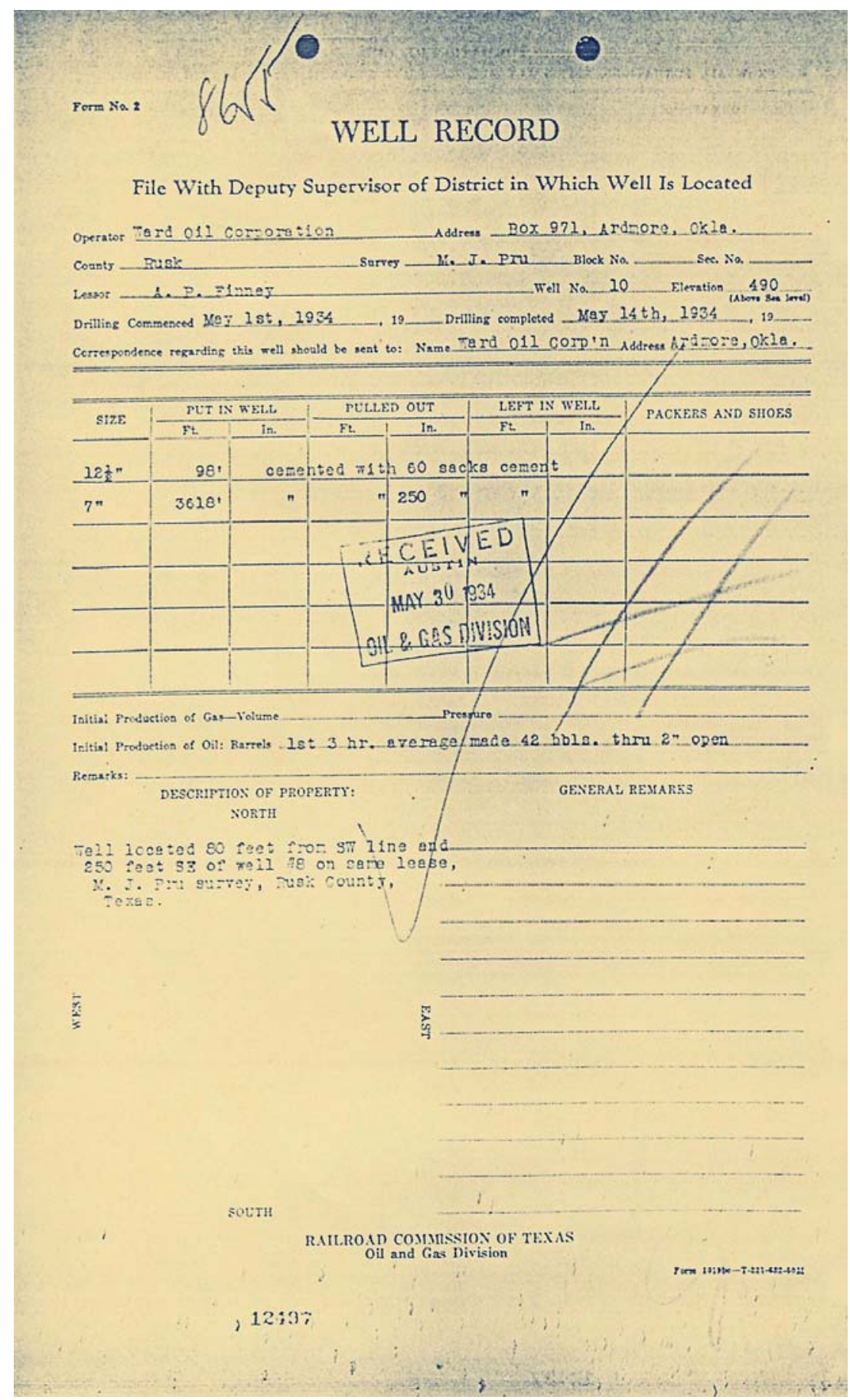

Figure 3. Page 1 of a typical drillers' log filed in the 1930's when the East Texas Field was first discovered. Records are available from the Texas Railroad Commission. 


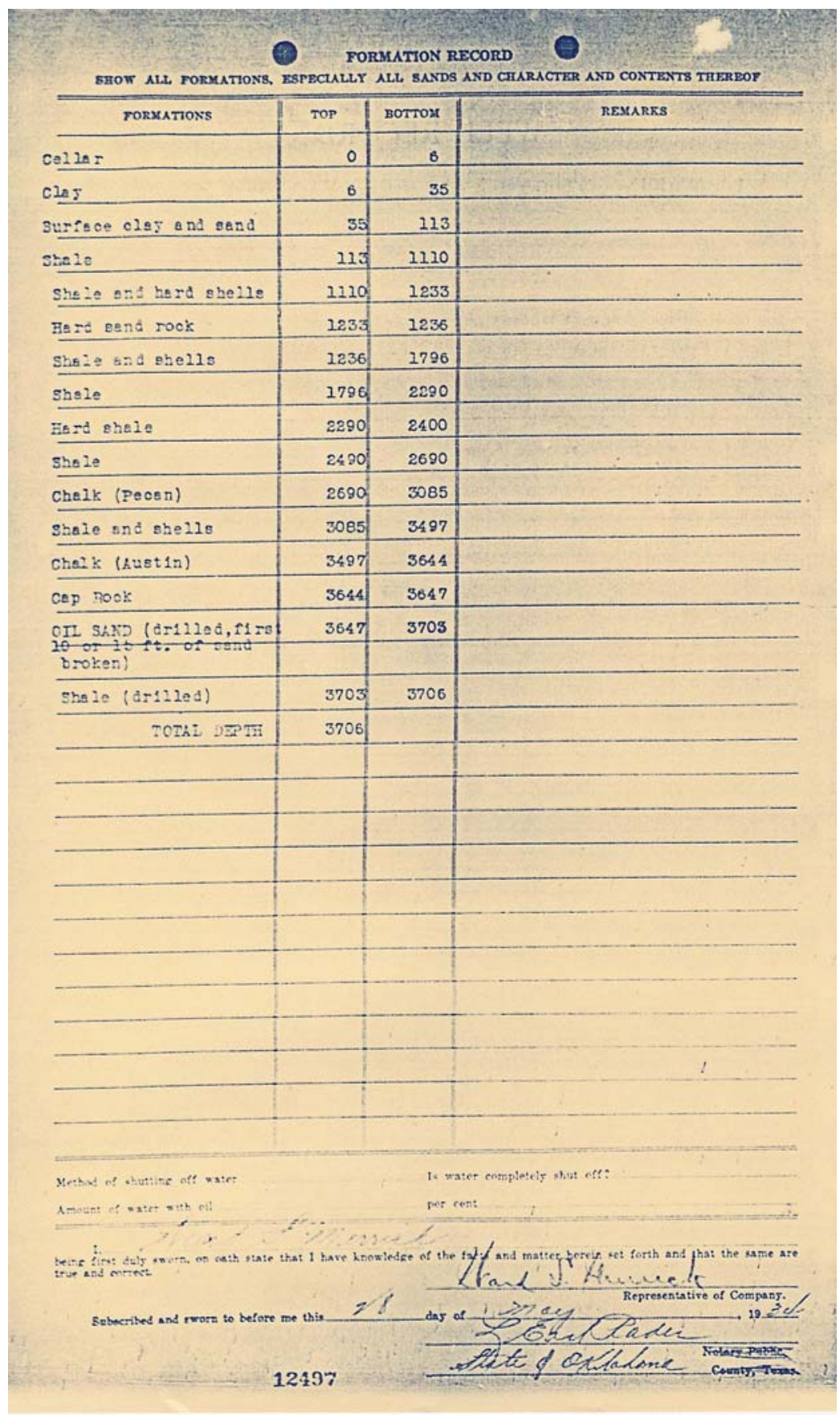

Figure 4. Page 2 of a typical drillers' log filed in the 1930's when the East Texas Field was first discovered. Records are available from the Texas Railroad Commission. 
Table 1. Conversion chart for Drillers' log descriptive lithology to numerical format.

\begin{tabular}{|c|c|}
\hline Description & $\underline{\text { Value }}$ \\
\hline Chalk, lime cap bank, lime & 100 \\
\hline hard lime rock, broken lime & 100 \\
\hline Austin chalk & 100 \\
\hline broken chalk & 100 \\
\hline hard lime \& boulders & 100 \\
\hline hard rock, cap rock, & 100 \\
\hline soft chalk, sticky chalk & 100 \\
\hline Pecan Gap chalk & 100 \\
\hline Pecan Gap hard & 100 \\
\hline cap rock, hard cap, hard chalk & 100 \\
\hline broken oil sand & 1 \\
\hline oil sand, hard oil sand & 1 \\
\hline sand, sand rock & 10 \\
\hline soft sand \& hard sand & 10 \\
\hline Woodbine sand & 10 \\
\hline hard sand \& pyrites & 10 \\
\hline shale, sticky shale, hard shale & 60 \\
\hline broken shale \& shells & 60 \\
\hline shale \& lime shell & 80 \\
\hline brown lime \& shale & 80 \\
\hline shale \& shells, chalk \& shale & 80 \\
\hline broken chalk \& sticky shale & 80 \\
\hline shale \& rock & 80 \\
\hline hard rock \& shale & 80 \\
\hline shale, streak chalk & 80 \\
\hline shale \& broken chalk & 80 \\
\hline broken chalk \& shale & 80 \\
\hline shale \& lime streaks & 80 \\
\hline hard lime shale & 80 \\
\hline hard sandy lime & 90 \\
\hline hard sandy shale & 40 \\
\hline shale \& sand & 40 \\
\hline shale \& broken sand & 40 \\
\hline sand \& sticky shale & 40 \\
\hline shale, streak sand & 40 \\
\hline packed sand, hard & 40 \\
\hline broken sand \& shale & 40 \\
\hline hard sandy shale, shells & 40 \\
\hline hard sand, streak shale & 40 \\
\hline sandy shale & 40 \\
\hline shale, shells, streak sand & 40 \\
\hline
\end{tabular}


Table 2. An example of a database record containing numeric values for the driller's and geophysical logs.

\begin{tabular}{|c|c|c|c|c|c|c|}
\hline $\begin{array}{l}\text { WELL ID } \\
========\end{array}$ & $\begin{array}{c}\text { TYPE } \\
======\end{array}$ & $\begin{array}{l}\text { SRF.CRD.X } \\
========\end{array}$ & $\begin{array}{l}\text { RF.CRD.Y } \\
=======\end{array}$ & $\begin{array}{l}\text { ELEV } \\
=====\end{array}$ & $\begin{array}{l}\text { T.D. } \\
:====\end{array}$ & $\begin{aligned} & \text { WS } \\
= & ===\end{aligned}$ \\
\hline 1 & VERT & 318555.0 & 3565854.0 & 448.0 & 3683 & 6 \\
\hline $\begin{array}{l}\text { DEPTH-TOP } \\
=========\end{array}$ & $\begin{array}{c}\text { GR-API } \\
======\end{array}$ & $\begin{array}{c}\text { DRL LOG } \\
=======\end{array}$ & & & & \\
\hline 0 & 99 & 99 & & & & \\
\hline 3550 & 71 & 80 & & & & \\
\hline 3552 & 70 & 80 & & & & \\
\hline 3554 & 75 & 80 & & & & \\
\hline 3556 & 90 & 80 & & & & \\
\hline 3558 & 105 & 80 & & & & \\
\hline 3560 & 98 & 80 & & & & \\
\hline 3562 & 90 & 80 & & & & \\
\hline 3564 & 98 & 80 & & & & \\
\hline 3566 & 75 & 80 & & & & \\
\hline 3568 & 75 & 100 & & & & \\
\hline 3570 & 80 & 100 & & & & \\
\hline 3572 & 85 & 100 & & & & \\
\hline 3574 & 81 & 100 & & & & \\
\hline 3576 & 90 & 100 & & & & \\
\hline 3578 & 80 & 100 & & & & \\
\hline 3580 & 67 & 100 & & & & \\
\hline 3582 & 75 & 100 & & & & \\
\hline 3584 & 75 & 10 & & & & \\
\hline 3586 & 70 & 10 & & & & \\
\hline 3588 & 52 & 10 & & & & \\
\hline 3590 & 50 & 10 & & & & \\
\hline 3592 & 50 & 10 & & & & \\
\hline 3594 & 50 & 10 & & & & \\
\hline 3596 & 70 & 10 & & & & \\
\hline 3598 & 60 & 10 & & & & \\
\hline 3600 & 60 & 10 & & & & \\
\hline 3602 & 75 & 10 & & & & \\
\hline 3604 & 77 & 10 & & & & \\
\hline 3606 & 85 & 10 & & & & \\
\hline 3608 & 85 & 10 & & & & \\
\hline 3610 & 67 & 10 & & & & \\
\hline 3612 & 65 & 10 & & & & \\
\hline 3614 & 86 & 10 & & & & \\
\hline 3616 & 97 & 10 & & & & \\
\hline 3618 & 105 & 10 & & & & \\
\hline 3620 & 100 & 10 & & & & \\
\hline 3622 & 105 & 10 & & & & \\
\hline 3624 & 110 & 10 & & & & \\
\hline 3626 & 105 & 10 & & & & \\
\hline 3628 & 80 & 10 & & & & \\
\hline 3630 & 90 & 10 & & & & \\
\hline
\end{tabular}




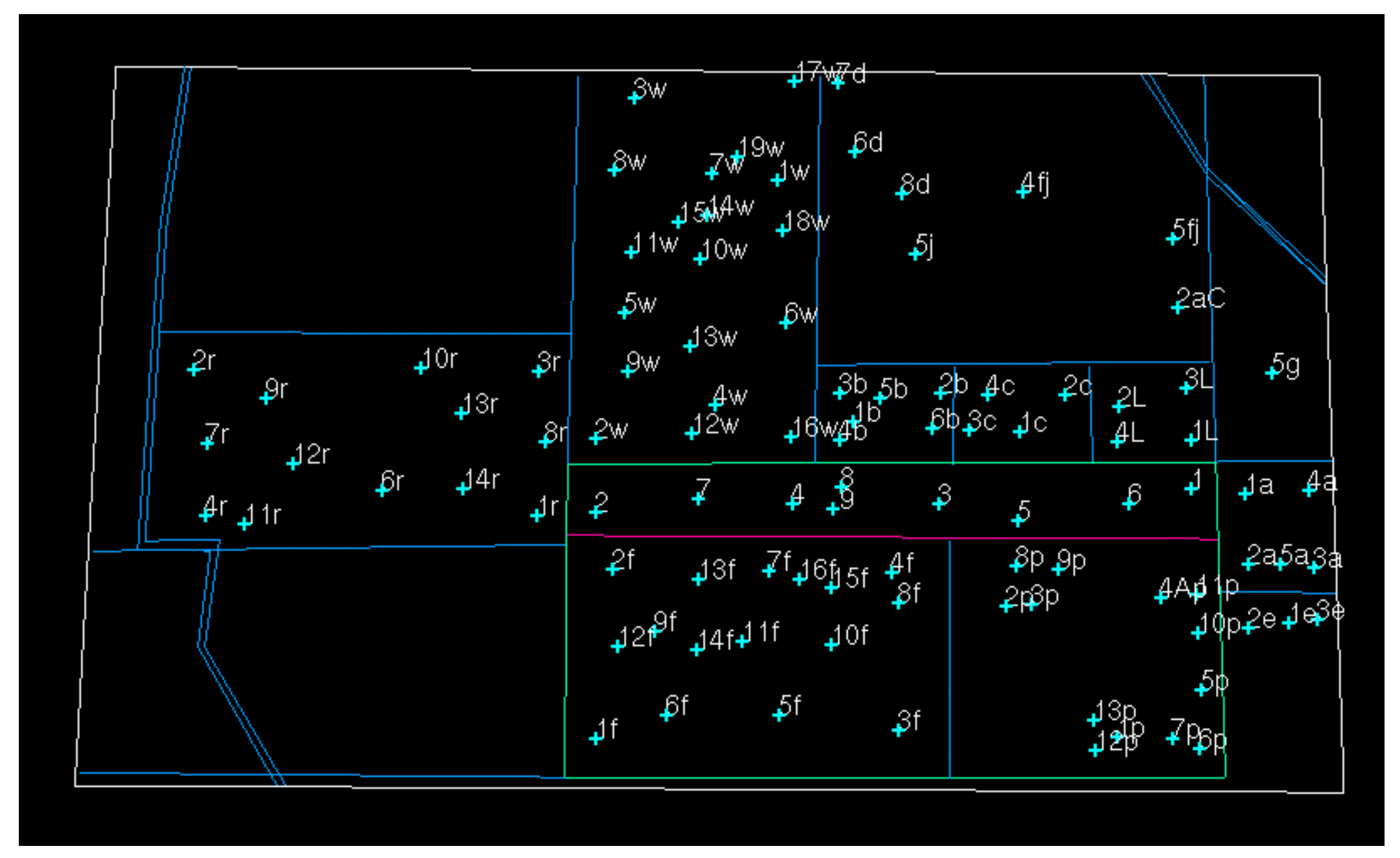

Figure 5. Distribution of wells from which drillers' logs were available in the proximity of the project lease. 


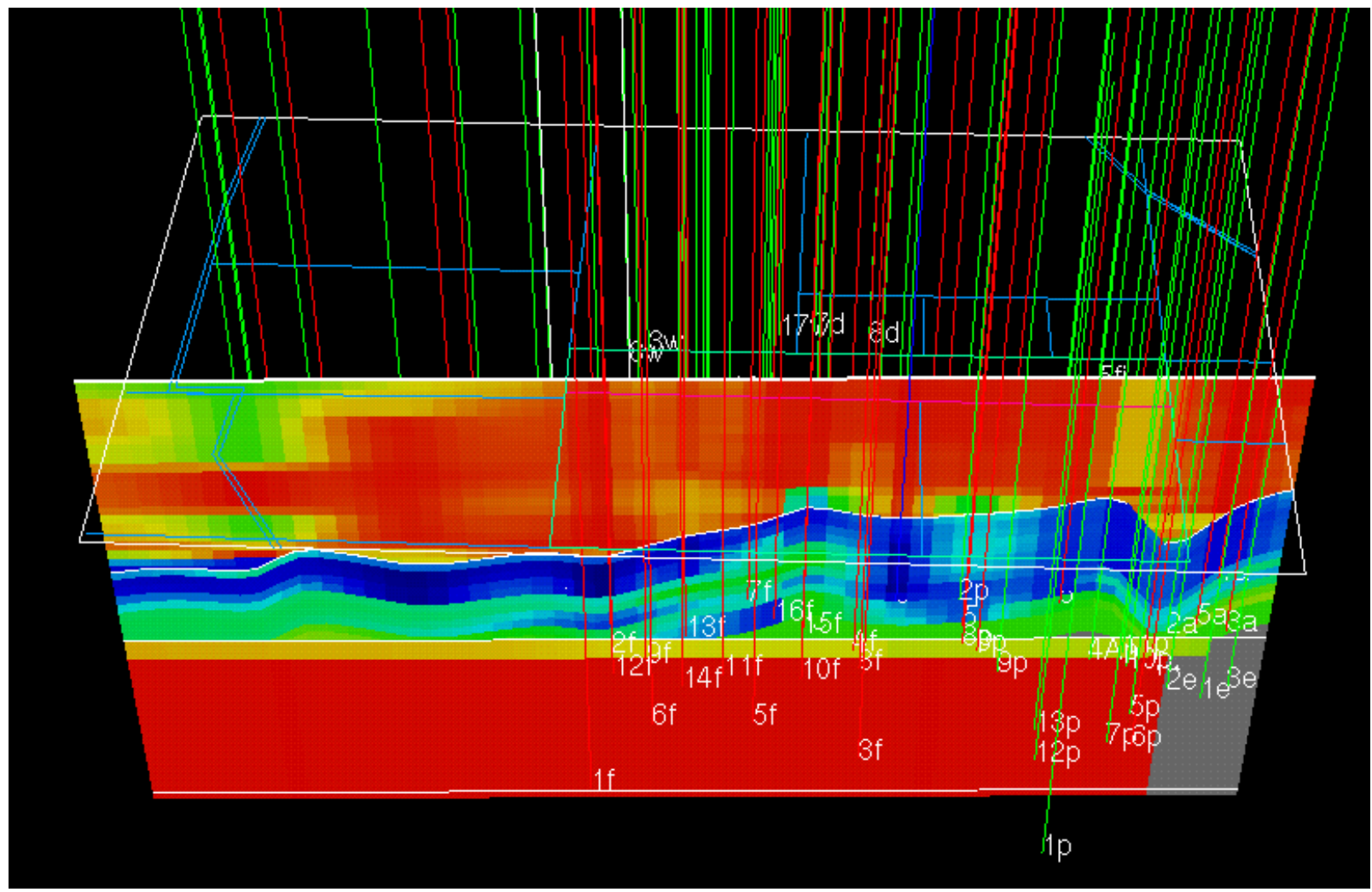

Figure 6. East -west section through the lease depicting the Woodbine sand. The dark blue correlates the oil sand and clean sand zones and the green indicates increasing clay content. Austin Chalk or carbonate sediments are displayed in red. Lease lines are superimposed at the top of the image and wells from which drillers' logs were obrtained are shown as wellbores. Green wellbores are producing wells and red wellbores are plugged or shut-in wells. Vertical scale is exagerated but the entire Woodbine sand section is approximately 150 feet thick. Horizontal scale across the image is approximately 2 miles. 


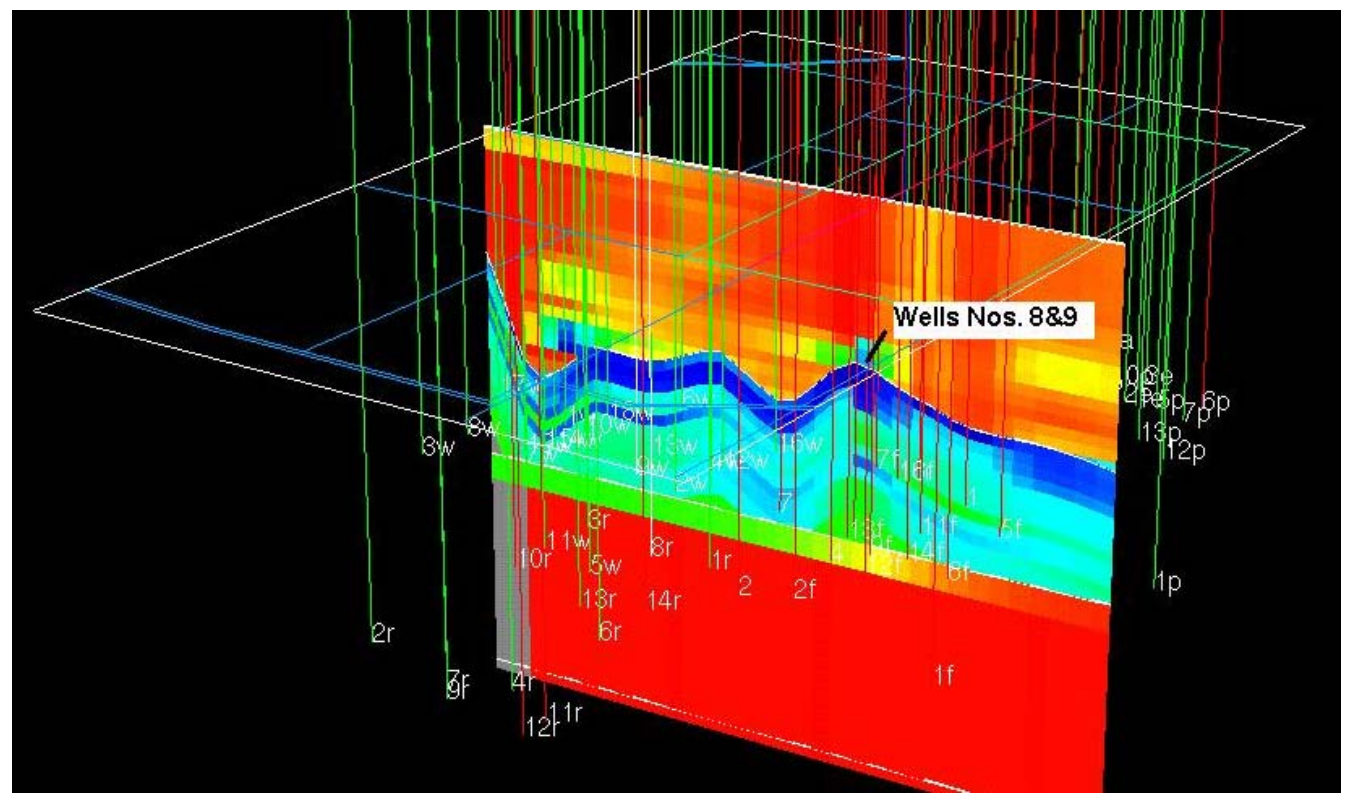

Figure 7. A north-south section through wells Nos. 8 \& 9 located on the stratigraphic high point of the Woodbine sand. The dark blue correlates the oil sand and clean sand zones and the green indicates increasing clay content. Austin Chalk or carbonate sediments are displayed in red. Lease lines are superimposed at the top of the image and wells from which drillers' logs were obrtained are shown as wellbores. Green wellbores are producing wells and red wellbores are plugged or shut-in wells. Vertical scale is exagerated but the entire Woodbine sand section is approximately 150 feet thick. Horizontal scale across the image is approximately 2 miles. 


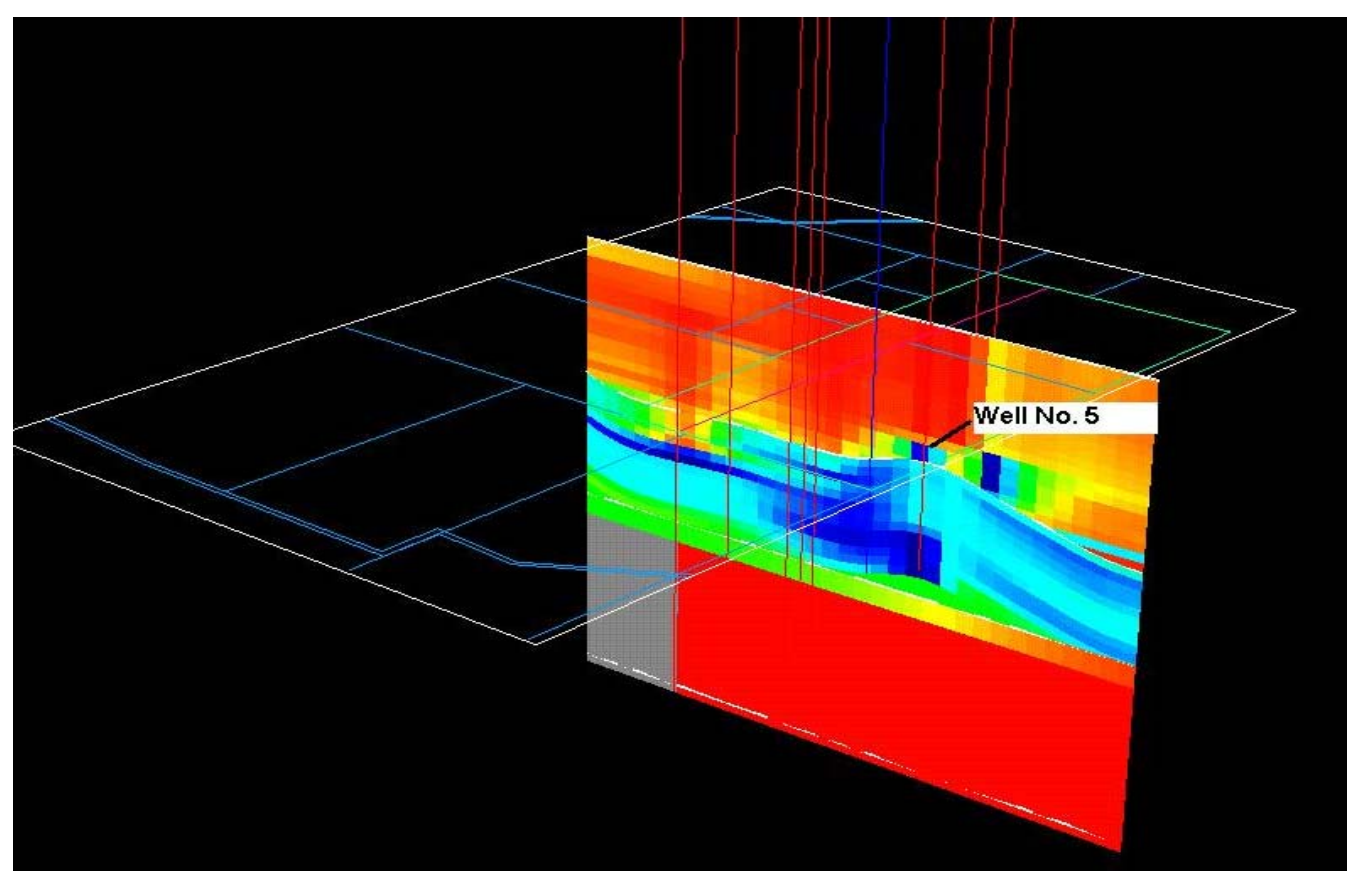

Figure 8. A north-south section through wells No. 5 located on the stratigraphic high point of the Woodbine sand. The dark blue correlates the oil sand and clean sand zones and the green indicates increasing clay content. Austin Chalk or carbonate sediments are displayed in red. Lease lines are superimposed at the top of the image and wells from which drillers' logs were obrtained are shown as wellbores. Green wellbores are producing wells and red wellbores are plugged or shut-in wells. Vertical scale is exagerated but the entire Woodbine sand section is approximately 150 feet thick. Horizontal scale across the image is approximately 2 miles. 


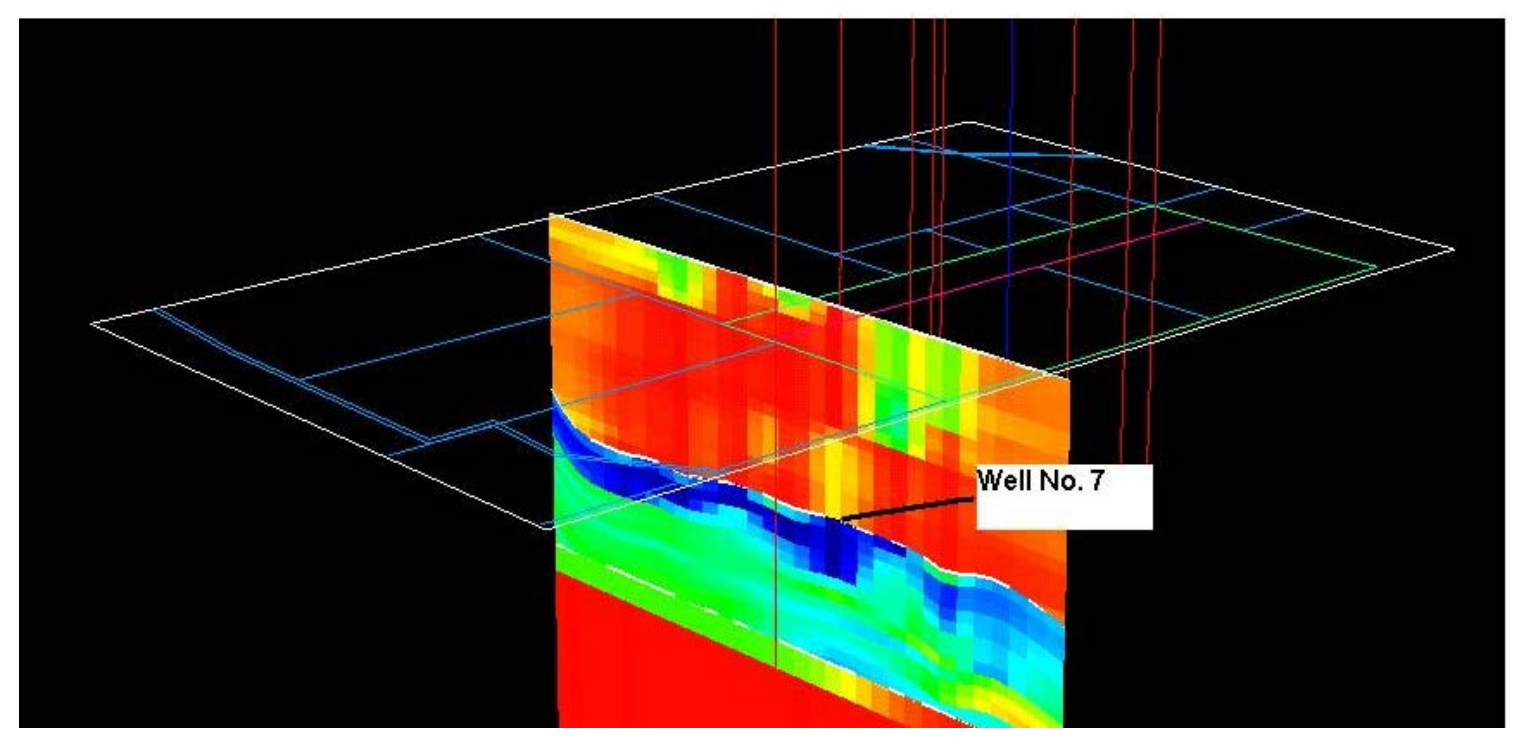

Figure 9. A north-south section through well No. 7 located on the stratigraphic high point of the Woodbine sand although the prominence of the sand has flattened. The dark blue correlates the oil sand and clean sand zones and the green indicates increasing clay content. Austin Chalk or carbonate sediments are displayed in red. Lease lines are superimposed at the top of the image and wells from which drillers' logs were obrtained are shown as wellbores. Green wellbores are producing wells and red wellbores are plugged or shut-in wells. Vertical scale is exagerated but the entire Woodbine sand section is approximately 150 feet thick. Horizontal scale across the image is approximately 2 miles. 


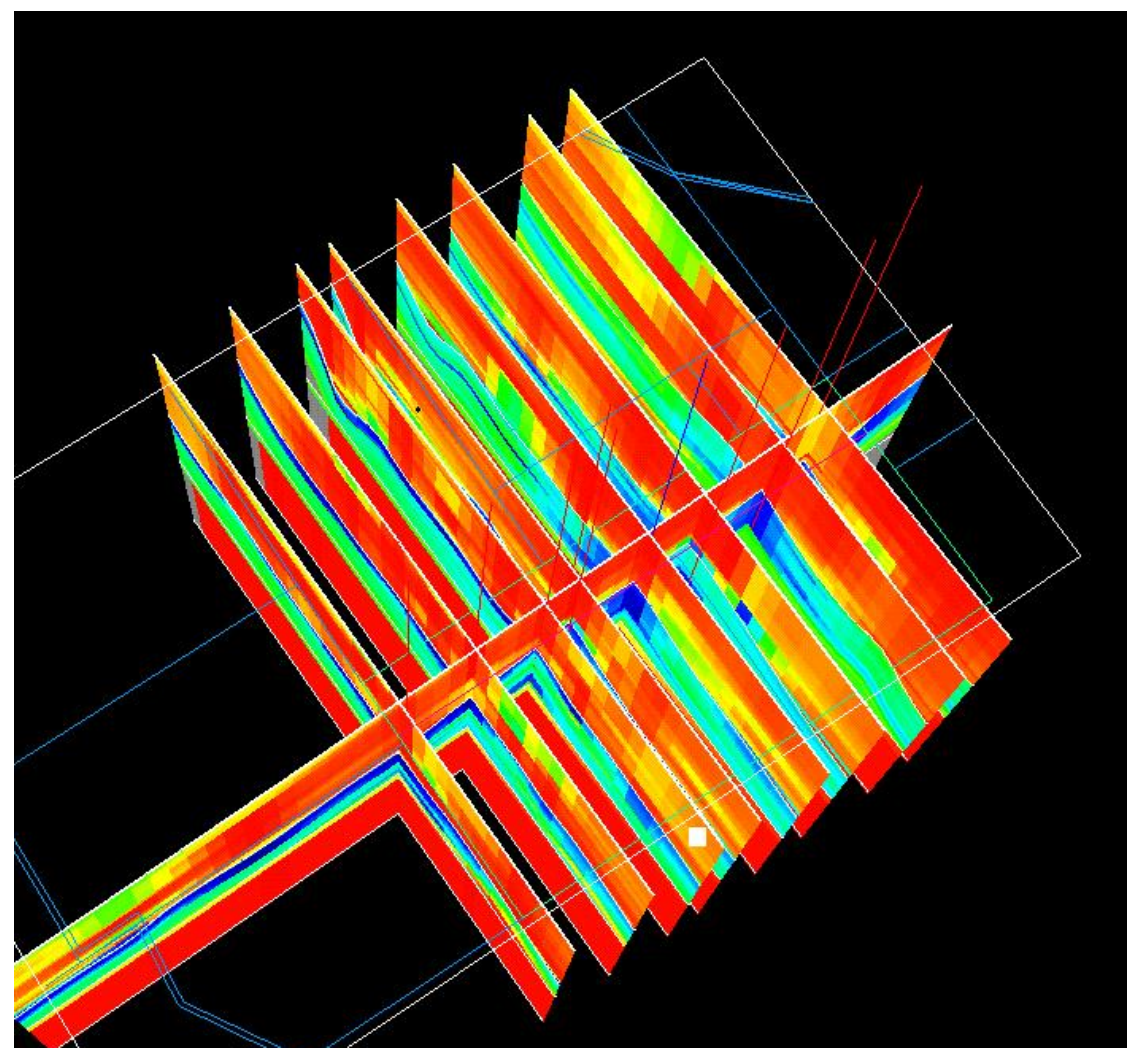

Figure 10. A top view of the project lease with north-south sections through each lease well. Note the stratigraphic ridge through the center of the lease. The dark blue correlates the oil sand and clean sand zones and the green indicates increasing clay content. Austin Chalk or carbonate sediments are displayed in red. Lease lines are superimposed at the top of the image and wells from which drillers' logs were obrtained are shown as wellbores. Green wellbores are producing wells and red wellbores are plugged or shut-in wells. Vertical scale is exagerated but the entire Woodbine sand section is approximately 150 feet thick. Horizontal scale across the image is approximately 2 miles.

\section{Task 2: Borehole Logging}

TENECO Energy in co-operation with Schlumberger's technical staff evaluated the most effective tools for determining the remaining oil in place. Borehole logging during drilling avoids the complication of having to log through steel casing; consequently the range and accuracy of geophysical tools is much greater. Logging through casing has historically been limited to neutron or gamma ray tools and in the East Texas Field a common logging approach was the Chlorinilog (Dresser Atlas) which was used on a periodic basis to detect changes in the oil water contact. 
The least expensive new approach would be to use a Reservoir Saturation Tool (RST) which can measure the oil and water content of the existing porosity and will work through casing. The tool can be used in two modes either Thermal Decay Time (TDT) or gamma ray spectrometry (GST). The TDT measurement is a historically proven technique for distinguishing water and oil especially for more saline reservoirs. For the East Texas Field it was discovered that the TDT tool was problematic because the water salinity was low $(\sim 30,000 \mathrm{ppm} \mathrm{Cl})$ and the difference between the fluids would be difficult to detect. The estimate for percentage of oil remaining would have a large uncertainty, if the difference between the oil and formation water could be detected at all. Because the quantification of residual oil in this mature reservoir is a primary objective of this research; this geophysical approach was not recommended by Schlumberger.

Schlumberger has made significant recent advancements with the RST-GST technology. It is commonly referred to as the Carbon Oxygen tool $(\mathrm{C} / \mathrm{O})$ and uses neutron scattering to generate gamma rays that are measured with a gamma ray spectrometer. Because the energy spectra of the elements are measured, rather than relying on a difference in properties such as resistivity, the tool can detect elemental content directly. This allows for computer processing that yields estimates for mineralogy, lithology, porosity, and a direct measurement of carbon and water in the pore space. Furthermore, the newest versions of this tool are not only deployed in casing but are slim enough to fit in tubing. The cost of running the log is substantially more than for the standard TDT, but this log can be run without having to remove the tubing which is a cost savings.

We selected this tool for the project and ran the C/O log on three wells the Nos. 1, 5 and 9. These wells were selected because they represent a geologic section though the lease which is aligned along the dip of the Woodbine reservoir. Figures 11-13 shown below represent the processed results and are displayed in a RST-C format. 
Table 3. Logging parameters employed for the RST-GST tool.

\begin{tabular}{|c|c|}
\hline Location & Rusk County, Texas \\
\hline Lease & J.M. Finney \\
\hline Wells Logged & No. 1 , No. 5 , No. 9 \\
\hline Tool & All wells logged with the RST-C tool \\
\hline Interpretation & Schlumberger RST ELAN Analysis \\
\hline Capture Logging Speed & 600 feet per hour \\
\hline Spectral Passes logging Speed & 25 feet per hour \\
\hline Depth Record & Line measurements, IDW Method \\
\hline Records & 1 pass, each mode, TD through Austin Chalk \\
\hline $\begin{array}{l}\text { Borehole No.1 } \\
\text { Top of Woodbine Sand }\end{array}$ & 7" casing, 5" liner, tubing mixed 2 3/8" and 2 7/8" \\
\hline Potential Oil Zones & 3590', 3602' and 3644' depth \\
\hline $\begin{array}{l}\text { Borehole No.5 } \\
\text { Top of Woodbine Sand }\end{array}$ & 7" casing, mixed 2 3/8” and 2 7/8” \\
\hline Potential Oil Zones & 3595 ' to 3610 ' depth \\
\hline $\begin{array}{l}\text { Borehole No.9 } \\
\text { Top of Woodbine Sand }\end{array}$ & 7" casing, 5" liner, tubing mixed 2 3/8" and 2 7/8" \\
\hline Potential Oil Zones & 3622 ' to 3624 ' depth \\
\hline
\end{tabular}




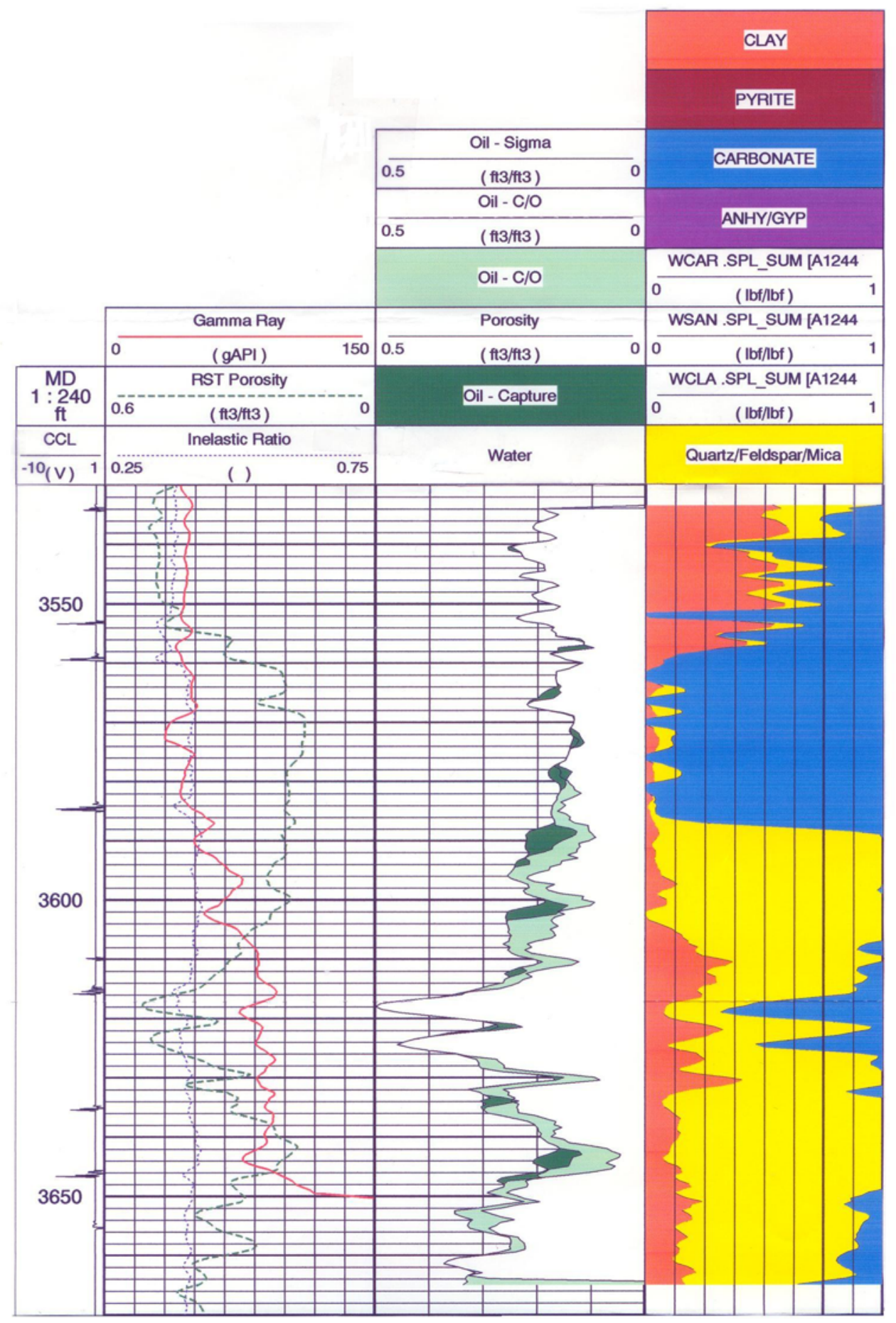

Figure 11. RST-C log of well No. 1. The second panel is the computed log for saturation; dark green is the TDT and the light green is the GST. The third panel displays the distinct contact of the Austin Chalk (blue) and the top of the Woodbine sand ( 3587') shown in yellow, and indicates that the oil saturation is approximtely $50 \%$. 


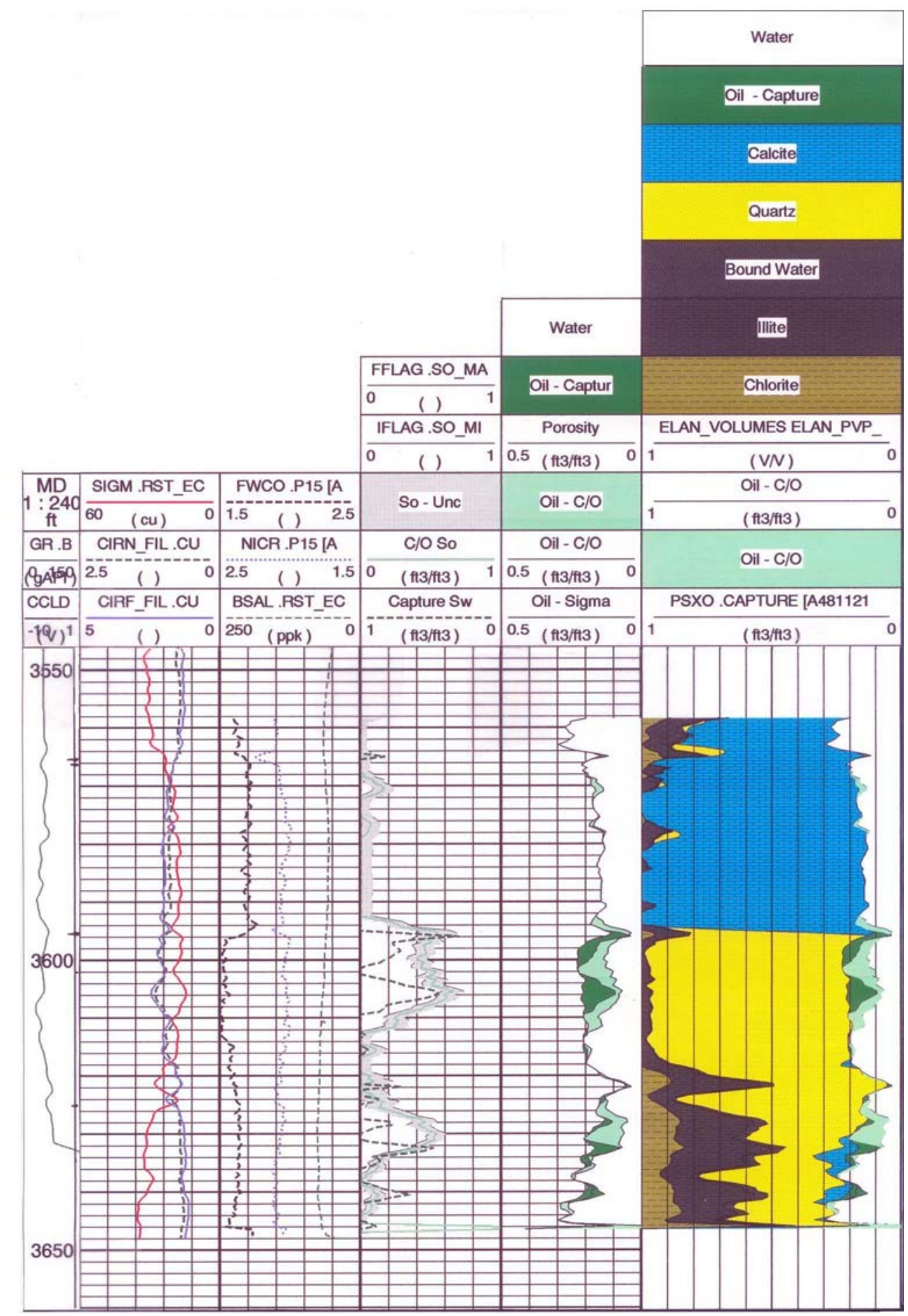

Fig 12. RST-C log of well No. 5. The fifth panel is the computed log for saturation; dark green is the TDT and the light green is the GST. The sixth panel displays the distinct contact of the Austin Chalk (blue) and the top of the Woodbine sand ( 3595') shown in yellow, and indicates that the oil saturation is approximtely $50 \%$. 


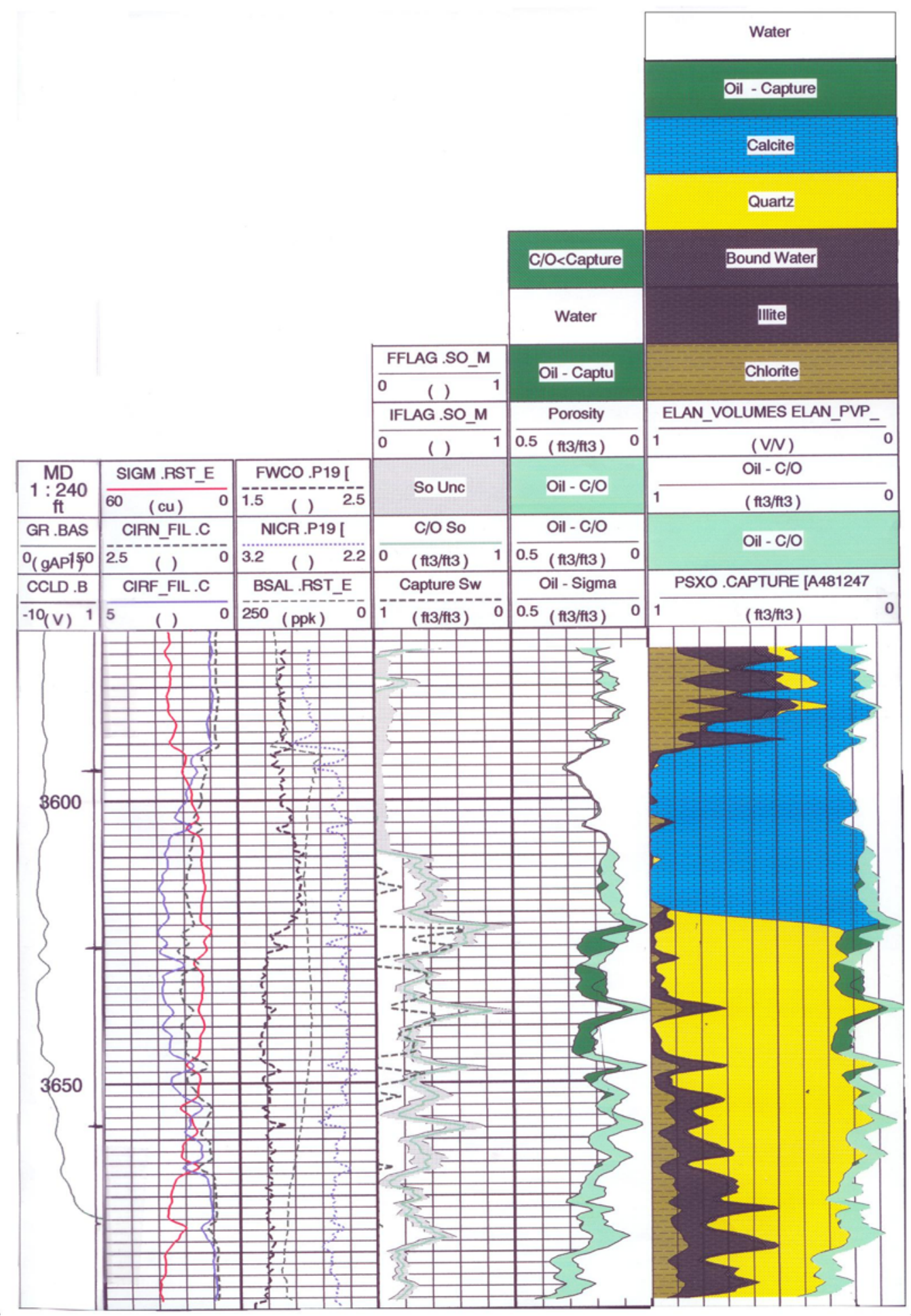

Fig.13. RST-C log of well No. 9. The fifth panel is the computed log for saturation; dark green is the TDT and the light green is the GST. The sixth panel displays the distinct contact of the Austin Chalk (blue) and the top of the Woodbine sand ( 3622') shown in yellow, and indicates that the oil saturation is approximtely $50 \%$. 
The two most successful results obtained from using the $\mathrm{C} / \mathrm{O}$ logging tool are the lithologic definition and the detection of residual oil (Figs. 3-5). First note that the measurement of elements using neutron scattering provides sufficient information to define lithology, which is displayed in color codes in the sixth panel from the left on all three logs. The formation contact between the producing reservoir, the Woodbine sand shown in yellow, and the overlying Austin Chalk, a dense limestone shown in blue, is clear and well defined. The location of this contact is extremely important because the reservoir is a water drive and the residual oil will generally be found at the top of the sand zone near the Austin Chalk contact.

Furthermore, note that the fifth panel is a display of porosity and percentage of oil and water currently in place. The total porosity is displayed on a scale of 0 to $50 \%$; the water leg (white), and the hydrocarbon leg (green) represent the total porosity because this reservoir does not have a free gas phase remaining. The total porosity ranges to greater than $30 \%$. The RST log measures carbon and chloride directly rather that rely on a difference technique, so the depiction of oil is actual hydrocarbon. The hydrocarbon fraction is displayed in two shades of green; the dark green represents the TDT measurement which was incorporated to display the difference between it and the GST (light green). As predicted the TDT measurement was not robust and because of low salinity it does not reveal the location of the bulk of the remaining oil. The GST trace is much more successful in identifying the presence and distribution of hydrocarbon and this result is displayed as the light green. Note that as suspected the top of the Woodbine contains the highest percent of residual oil, in some intervals as high as $50 \%$, and that distribution of oil is much more extensive than could have been determined by TDT analysis alone. It is also significant that the sand near the top of the Woodbine is cleaner i.e. contains much less clay, and therefore the percent of immobile oils would be expected to be much less.

The benefit derived from logging all three wells is obvious, especially from the information content provided. The objective was to determine if oil still remained on these leases, and similarly was likely present throughout the field, after producing these wells for seventy years. The geophysics clearly indicates that the upper Woodbine has zones near the top of the reservoir with oil saturations in excess of $50 \%$. This should be a significant fraction and would be economic to recover.' 


\section{Task 3: Selection of Demonstration Well and Potential Zones for Testing}

The objective of this task is to combine the information obtained from the $3 \mathrm{D}$ geological simulations with the information acquired by $\mathrm{C} / \mathrm{O}$ logging and assess the best well for additional testing of economic viability. The evaluation should include oil saturation, extent of reservoir sand, continuity of sands, structural position of the reservoir, and determine which well should be tested. The No. 1 well is structurally the highest, it has excellent reservoir sand and oil saturation in the upper zone at 3587' to 3596' is in excess of 50 percent.

One of the dilemmas encountered in the East Texas field is the absence of records. Many engineering details are lost as leases are transferred to new operators. Information filed with the TRC can be retrieved but this is minimal summary information. W-12 forms obtained from the TRC for well No.1 indicate that the No. 1 has open perforations below the preferred zone of interest, but the open zones (3607' to 3612'; and 3649' to 3656') do indicate oil in place (Figure 2).

The conclusions regarding this task are the following:

1. Based on the information gained in Tasks 1 and 2, the No. 1 well is the well with the highest probability of economic success;

2. In the No. 1 well the interval most likely to be productive is at the top of the Woodbine sand at 3587' to 3596' with oil saturation in excess of 50\%.

3. The intervals currently perforated are below this most favorable zone but the $\mathrm{C} / \mathrm{O}$ logs indicated these intervals should be productive but less so than the preferred zone.

4. If the zones currently open are not economic, then the most favorable zone should be perforated and evaluated.

\section{Task 4: Installation of Submersible Pump/Perforation of Potential Zones}

The conventional approach to operations of the marginal wells in the East Texas Field has been to pump at higher rates as the oil percentage drops. Across the field the wells are progressively becoming uneconomic because of water encroachment and this issue was a prime consideration in the project. Basically the objective of this task was to improve the decision making process about whether to abandon wells or purchase larger production capabilities.

Pumping nearby wells with conventional pumping units indicated that the total fluid production for this area may be limited to the 100 to 200 barrels per day range. A submersible pump would provide pumping capacity of over 1000 barrels of fluid per day, but obviously would be excess capacity and non-economic at present. Discussions with DOE allowed a modification. An alternative to increasing oil production from potentially 
productive zones by increasing volume while maintaining oil percent, is to increase oil percent of the existing producing capability.

Schlumberger was contracted to set a bridge plug in the No. 1 well to isolate the target zone at the top of the Woodbine from two sets of perforations in the lower Woodbine. New perforations were shot in the upper zone at the interval computing saturations or $50 \%$ or greater.

The well immediately was producing approximately 3 BOPD and this continued to the end of the grant period. It is anticipated that oil content will increase as the fluid level in the borehole declines. This zone is one that was originally produced as an open hole when the well was drilled. The operator set a liner in the well in 1975 when the production was uneconomic for the current prices. The deeper sand zones often referred to as the "lower stringer" were opened to production (3714' - 3768') and the upper Woodbine was left isolated from production behind the liner. This project identified that residual oil was still present in significant quantity and tested this observation by opening the behind pipe reserve to production. 


\section{CONCLUSIONS}

1. Using descriptive drillers' logs and supporting information from E-logs, chlorinilogs and engineering data on well locations, depth and elevations, it was possible to create a 3 Dimensional geological image of the Woodbine sand for the project area in Rusk County, Texas.

2. The conversion of descriptive lithologic charts to digital information required developing a numerical scheme for the characterization of sand, clay and carbonate lithologies. The numerical database was input into a geostatistical program that correlated the lithologies between wells and provided a digital image that could be redrawn as cross sections at any angle or azimuth through the region of interest. The cross sections clearly indicated sand zones that were connected and yielded new information about the reservoir that was not available. The input data was all limited to existing data and did not require any additional geophysical information to create the 3 Dimensional displays.

3. Residual oil saturation was determined by running the Schlumberger RST-GST slimhole tool which can operate in tubing. The tool uses neutron scattering to generate gamma rays that indicated elemental content of the formation; from which lithology, porosity, and oil saturation can be determined.

4. Oil saturation was detected at the level of $50 \%$ or greater in zones at the top of the Woodbine sand. This detected oil supports the supposition that significant oil remains in the Woodbine even after seven decades of production, and though the majority of the wells in the field are marginal with high water percentage, it is likely that with judicious application of technology the residual oil can be exploited.

5. Prospective zones were perforated and even though the zones had been abandoned as non-productive almost three decades ago, the oil production returned and with further testing should prove to be economic. 


\section{REFERENCES}

Adolph B, Brady J, Flaum C, Melcher C, and Vittachi A, 1994, Saturation monitoring with the RST reservoir saturation tool. Oilfield Review, Jan., 29-39.

Schlumberger, Maxus 500 RST* Reservoir Saturation Tool. pp. 1-25.

Landmark Graphics Corporation, 1997. Learning Stratamodel. 365 p. 